\title{
Analytical validation of the PAM50-based Prosigna Breast Cancer Prognostic Gene Signature Assay and nCounter Analysis System using formalin-fixed paraffin-embedded breast tumor specimens
}

\author{
Torsten Nielsen ${ }^{1,4^{*}}$, Brett Wallden², Carl Schaper ${ }^{3}$, Sean Ferree², Shuzhen Liu', Dongxia Gao', Garrett Barry ${ }^{1}$ \\ Naeem Dowidar ${ }^{2}$, Malini Maysuria ${ }^{2}$ and James Storhoff ${ }^{2}$
}

\begin{abstract}
Background: NanoString's Prosigna ${ }^{\mathrm{TM}}$ Breast Cancer Prognostic Gene Signature Assay is based on the PAM50 gene expression signature. The test outputs a risk of recurrence (ROR) score, risk category, and intrinsic subtype (Luminal $\mathrm{A} / \mathrm{B}, \mathrm{HER} 2$-enriched, Basal-like). The studies described here were designed to validate the analytical performance of the test on the nCounter Analysis System across multiple laboratories.

Methods: Analytical precision was measured by testing five breast tumor RNA samples across 3 sites. Reproducibility was measured by testing replicate tissue sections from 43 FFPE breast tumor blocks across 3 sites following independent pathology review at each site. The RNA input range was validated by comparing assay results at the extremes of the specified range to the nominal RNA input level. Interference was evaluated by including non-tumor tissue into the test.

Results: The measured standard deviation (SD) was less than 1 ROR unit within the analytical precision study and the measured total SD was 2.9 ROR units within the reproducibility study. The ROR scores for RNA inputs at the extremes of the range were the same as those at the nominal input level. Assay results were stable in the presence of moderate amounts of surrounding non-tumor tissue ( $<70 \%$ by area).
\end{abstract}

Conclusions: The analytical performance of NanoString's Prosigna assay has been validated using FFPE breast tumor specimens across multiple clinical testing laboratories.

Keywords: PAM50, Analytical validation, ROR, Subtype, Breast cancer, Prosigna, NanoString, nCounter, Reproducibility, FFPE, Gene expression

\section{Background}

Molecular biomarkers have played an increasingly important role in identifying cancer patients with different prognostic outcomes and in predicting response to chemotherapy [1-3]. Molecular assays targeting these biomarkers are now routinely performed in local pathology labs to help guide treatment decisions in breast cancer [4,5], lung cancer [6], and colorectal cancer [7]. Gene expression analysis has helped identify distinct

\footnotetext{
* Correspondence: torsten@mail.ubc.ca

'British Columbia Cancer Agency, 3427 - 600 W 10TH Avenue, V5Z 4E6

Vancouver, BC, Canada

${ }^{4}$ Anatomical Pathology JPN 1401, Vancouver Hospital, 855 W. 12th Ave, V5Z

1 M9 Vancouver, BC, Canada

Full list of author information is available at the end of the article
}

molecular signatures in breast cancer that have different prognostic outcomes [8-10]. Multigene assays targeting $21-70$ genes are now routinely used in clinical practice to assess risk of recurrence in early stage breast cancer $[11,12]$, and prospective clinical trials are also underway to provide further supporting evidence for the clinical utility of these assays $[13,14]$. To date, breast cancer multigene clinical assays have been largely limited to central reference laboratories due to the complexity of performing the test. Ultimately, development of assays with a simplified workflow is required to move these multigene expression tests into the local pathology lab setting, where efficiencies such as shorter turnaround 
time and direct interaction between laboratory physicians and the clinicians will benefit active patient care.

The PAM50 gene signature measures the expression levels of 50 genes in a surgically resected breast cancer sample to classify a tumor as one of four intrinsic subtypes (Luminal A, Luminal B, HER2-enriched, and Basal-like) [15], which have been shown to be prognostic in both untreated (i.e. no adjuvant systemic therapy) and tamoxifen treated patient populations $[15,16]$. In addition to identifying a tumor's intrinsic subtype, the PAM50 signature generates an individualized score estimating a patient's probability of disease recurrence by weighting the molecular subtype correlations, a subset of proliferation genes, and pathologic tumor size $[15,16]$. The PAM50 test was adapted to be performed using the nCounter Analysis System in order to develop a simplified workflow that could be performed in a local pathology lab (Prosigna ${ }^{\mathrm{Tm}}$ Breast Cancer Gene Signature Assay, NanoString Technologies, Seattle). This technology uses multiplexed gene-specific fluorescently-labeled probe pairs [17] to measure gene expression in frozen or formalin-fixed paraffin-embedded (FFPE) tissues with equivalent ease and efficiency [18]. A recent clinical validation performed on RNA extracted from over 1000 FFPE tumor specimens from the ATAC clinical trial demonstrated that the Prosigna risk of recurrence (ROR) score, based on the PAM50 gene expression signature, added significant prognostic information beyond the Oncotype $\mathrm{DX}^{\circ}$ Recurrence Score ${ }^{\circ}$ in estimating the likelihood of distant recurrence in hormone receptor positive, post-menopausal breast cancer patients [19] treated with endocrine therapy alone. A second clinical validation study performed on over 1400 FFPE patient samples from the ABCSG-8 trial has independently confirmed the clinical validity and demonstrated additional prognostic value in node-positive patients and for the risk of late recurrence [20,21]. Based in part on the results from these clinical studies and the analytical studies described herein, NanoString obtained a CE Mark for its Prosigna assay in 2012, followed by US Food and Drug Administration (FDA) clearance in September of 2013.

Recently, requirements for demonstrating utility of a tumor biomarker were established that include not only clinical validity, but also analytical reproducibility and robustness [22,23]. The results of ATAC and ABCSG-8, including a follow up combined analysis of the two studies [24] meet this high level of evidence (Level I) for clinical validity using archived specimens [22]. The studies described herein were designed to test the analytical validity of decentralized use of the Prosigna assay across multiple clinical testing sites, following established guidelines [25]. These studies were also designed to validate procedures for training laboratory personnel to perform the Prosigna assay on the nCounter system.

\section{Methods}

\section{NanoString Prosigna assay}

The tissue input for the Prosigna assay was FFPE tissue that had been previously diagnosed to contain viable invasive breast carcinoma. The breast tumor tissue must be classified by a pathologist as invasive carcinoma (ductal, lobular, mixed, or no special type). A pathologist reviews an $H \& E$ stain of a slide mounted tumor section to identify and circle the region of viable invasive breast carcinoma. The tumor surface area on the H\&E stained section must be $\geq 4 \mathrm{~mm}^{2}$ per slide, with tumor cellularity $\geq 10 \%$. Non-tumor tissue from outside the circled area is removed by macrodissection of the corresponding unstained slides. RNA was extracted from slide mounted breast tissue sections using a RNA extraction kit manufactured by Roche to NanoString's specifications [26]. For RNA isolation, a single 10-micron slide mounted tissue section was input for RNA extraction when the tumor surface area measured $\geq 100 \mathrm{~mm}^{2}$, whereas 3 slides were input when the tumor surface measured 4-99 $\mathrm{mm}^{2}$. Following extraction of total RNA and removal of genomic DNA, RNA was eluted $(30 \mu \mathrm{L}$ volume) and tested to ensure it met the specifications for concentration ( $\geq 12.5 \mathrm{ng} / \mu \mathrm{L}$ ) and purity (OD 260/ $280 \mathrm{~nm} \mathrm{1.7-2.5).}$

The NanoString Prosigna assay [26] measures the expression levels of 50 target genes plus eight constitutively expressed normalization genes $[15,27,28]$. Assay controls are included to ensure that test samples and the test process meet pre-defined quality thresholds. Exogenous probes with no sequence homology to human RNA sequences are included as positive and negative assay controls. Positive controls are comprised of a six point linear titration of in vitro transcribed RNA covering an approximately 1000 fold RNA concentration range $(0.125-128 \mathrm{fM})$ and corresponding probes $[29,30]$. Negative controls consist of a set of probes without the corresponding targets. Each assay run includes two reference control samples comprising in vitro transcribed RNA of the 58 targets for qualification and normalization purposes.

Extracted RNA samples meeting quality and concentration specifications were hybridized (without reverse transcription or amplification) to capture and reporter probes for the measured genes and assay controls. The multiplexed hybridizations are carried out in a singletube for $15-21 \mathrm{hrs}$ at $65^{\circ} \mathrm{C}$ using $125-500$ ng RNA (nominal input of $250 \mathrm{ng}$ ). After hybridization, the target-probe complexes were processed on the nCounter Analysis System. Test sample data must meet a minimum threshold for expression of normalizing genes to ensure that the assay signal is high enough for the algorithm to produce precise results. The linearity of the positive control target titration and the non-specific 
background from negative control probes included in each assay is used to determine whether each assay performed within specification. Since the test is designed to be run in local molecular pathology labs, all quality thresholds are applied automatically to the data by embedded software; any failing metric causes an assay failure notice which prevents output of a Prosigna assay result. For samples meeting all quality thresholds, a clinically validated algorithm is used to determine the intrinsic subtype and ROR score, which are prognostic indicators of risk of distant recurrence of breast cancer $[19,21]$. The normalized gene expression profile of each breast tumor sample is correlated to prototypical gene expression profiles of the four breast cancer intrinsic subtypes (Luminal A, Luminal B, HER2-enriched, and Basal-like). The primary tumor size (categorical input of $\leq 2 \mathrm{~cm}$ or $>2 \mathrm{~cm}$ ) and normalized gene expression profile of each breast tumor sample is used to calculate the numerical ROR score. Risk categories are assigned to allow interpretation of the ROR score by using prespecified cutoffs (defined in a clinical validation study) related to risk of distant recurrence after 10 years [19].

Operators for these studies were required to undergo training procedures to demonstrate proficiency, equivalent to what will be used to train users in molecular pathology laboratories for the decentralized test. Each site was given an overview of the NanoString technology and Prosigna assay procedures followed by an in-lab exercise where users were trained and qualified on tissue processing and assay procedures (requiring 10-12 hours of total hands-on time). Briefly, each user extracted RNA from three FFPE breast tumor tissue samples to demonstrate proficiency in tissue processing, and each user processed four prototypical breast tumor RNA samples (one of each intrinsic subtype with known expected ROR score values) along with a negative control sample to demonstrate proficiency on the nCounter Analysis System.

The analytical studies described herein were performed using pre-specified SOPs, statistical analysis plans and acceptance criteria using clinical-grade reagents, instrumentation, and software formatted such that no comparison of results between test centers could even be possible until the study was completed.

\section{RNA precision: study design}

The RNA Precision study assessed the reproducibility of the Prosigna assay using a common template of purified RNA, thereby isolating the device-specific components of analytical validity from variables associated with tissue processing. The experimental design for analytically validating the precision of the assay from RNA was based on Clinical Laboratory and Standards Institute (CLSI) guidelines for the evaluation of precision of in vitro diagnostic devices outlined in EP05-A2 [25]. This design measured the variability between and within a number of assay variables including testing site $(\mathrm{n}=3)$, operator $(n=6)$, reagent lot $(n=3)$ and assay run $(n=18 /$ site $)$. Two of the three sites used were CLIA-certified, CAP-accredited laboratories at the British Columbia Cancer Agency (Vancouver), and Washington University (St. Louis); the third site was NanoString Technologies (Seattle).

Five pooled breast tumor RNA samples were generated from archived FFPE breast tumor tissue samples containing viable invasive breast carcinoma, to comprise a sample set representing each intrinsic breast cancer subtype and risk classification group (Table 1). Since the samples were pooled breast tumor RNA, a default tumor size category of $\leq 2 \mathrm{~cm}$ was used to determine the estimated ROR score, and a default nodal status of nodenegative was used to determine risk category. This design ensured that the prototypical gene expression profiles encountered during routine testing were represented within this analytical validation study. Since Luminal subtypes make up the vast majority of the intended use population (hormone receptor positive patients), the study design included three Luminal samples to span the risk classification groups. The identity of each sample aliquot was deidentified using labeled sample tubes with unique, randomly assigned, barcoded IDs to ensure that the operators were blinded to any possible expected results of each test sample.

Single use aliquots of each pooled breast tumor RNA sample and three reagent lots were distributed to each of the three testing sites to complete the following testing scheme (Figure 1). Each of the five RNA pooled samples was tested in duplicate during each run at the nominal RNA input level for the assay of $250 \mathrm{ng}$. The positions of the tumor RNA samples within the system (cartridge and strip tube position) were pre-assigned in a randomized and balanced manner for each run. Each operator completed one run on a given day since the assay includes an overnight hybridization step qualifying it as a "long run method" per CLSI EP05-A2. Following a device and study protocol familiarization run, each site completed 18 valid runs (9 by each operator) (Figure 1).

Table 1 RNA precision study sample summary

\begin{tabular}{ccc}
\hline $\begin{array}{c}\text { Intrinsic } \\
\text { subtype }\end{array}$ & $\begin{array}{c}\text { Estimated } \\
\text { ROR score }\end{array}$ & $\begin{array}{c}\text { Risk } \\
\text { classification }\end{array}$ \\
\hline Luminal A & 30 & Low \\
Luminal B \#1 & 54 & Intermediate \\
Luminal B \#2 & 64 & High \\
Basal-like & 55 & Intermediate \\
HER2-enriched & 76 & High \\
\hline
\end{tabular}

Molecular characteristics of the five pooled breast tumor RNA samples used in the RNA precision study. 


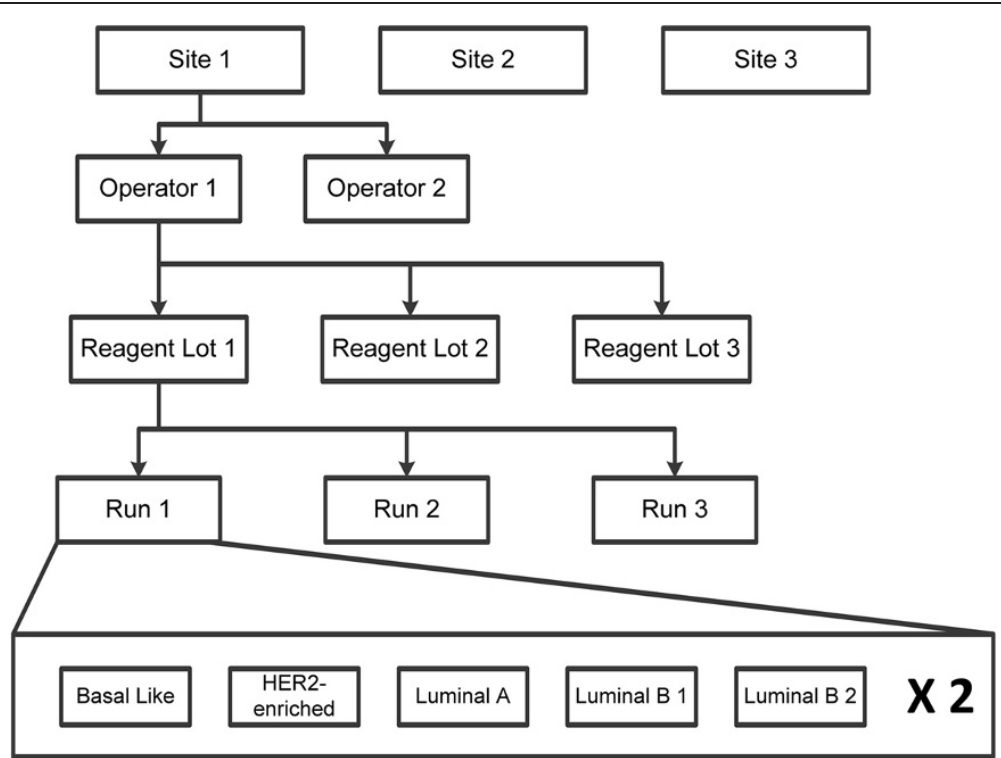

Figure 1 Overview of the design for the RNA precision validation study. Five pooled breast tumor RNA samples were tested across several sites, operators, reagent lots, and runs.

Upon completion of the study the blinded data were collected from each site and merged with the expected test result and study variables (site, operator, reagent lot, etc.) associated with each unique sample ID. The prospectively defined analysis plan was then executed on the merged analysis dataset.

\section{RNA precision: statistical analysis}

The pre-specified primary aim of the RNA precision validation was to demonstrate that there was no significant differences for the continuous ROR score assay output across the three testing sites.

The following variance components model was used to characterize the sources of variability:

ROR Score $=$ site + operator + lot + run + within-run

where all components were treated as random components, and the RNA assay component of variation was defined as the sum of all these components. Variance components were estimated using the $\mathrm{R}$ procedure "lmer". To test whether sites were significantly different, the following versions of the above model were fitted:

ROR Score $=$ site + operator + lot + run + within-run

$\&$ ROR Score $=$ operator + lot + run + within-run

where site was now treated as fixed and all other components were treated as random. A likelihood ratio test with 2-degrees of freedom was performed using the fitted models to determine whether the effect of site was significant $(\alpha=0.05)$. A similar analysis was performed for the assay reagent lots.

For each of the 5 pooled samples, the classifications into the 4 intrinsic subtype categories (Luminal A, Luminal B, Basal-Like, HER2-enriched) were summarized using frequency tables.

\section{Reproducibility: study design}

The reproducibility study assessed the analytical validity of the Prosigna assay, including all steps involving in clinical lab implementation (i.e. tissue handling and RNA isolation SOPs as well as the device-specific assay steps), using a common set of breast cancer tissue samples.

The experimental design for analytically validating the reproducibility from tissue was based on CLSI guidelines for the evaluation of precision of in vitro diagnostic devices outlined in CLSI EP05-A2. This design allows for the measurement of variability between and within a number of assay variables including testing site, FFPE sample block, operator, reagent lot, and assay run.

A set of 43 banked FFPE breast tumor blocks from hormone receptor positive breast cancer patients with confirmed invasive breast carcinoma was selected from the biobank at Washington University at St. Louis for this reproducibility validation study. The sample collection and conduct of this study were conducted in compliance with the study protocols and local IRB procedures. One 
FFPE block for each case was selected using the following criteria:

1. Every case should represent a unique breast cancer patient

2. All must be primary breast cancers

3. All are pathology confirmed invasive ductal or lobular carcinoma, a mixtures of these types, or classified as no special type

4. All are hormone receptor positive $(\mathrm{ER}+$ or $\mathrm{PgR}+)$ breast cancer

5. All must have a recorded tumor size

6. FFPE blocks should be $<10$ years old

7. A minimum of 10 cases each of $\geq 100 \mathrm{~mm}^{2}$ tumor area (1 slide/test) and $4-100 \mathrm{~mm}^{2}$ tumor area (3 slides/test)

The criterion that at least 10 cases contain $\geq 100 \mathrm{~mm}^{2}$ and at least 10 cases contain $4-99 \mathrm{~mm}^{2}$ tumor area was implemented to validate the number of slides required for the assay. The blocks were not prescreened with the assay prior to inclusion, but it was anticipated that the 43 samples would cover a broad range of ROR scores representative of the intended use population, including both node-negative and node-positive patients, and each risk classification group. Seventeen tissue samples were from node-negative patients, 6 from node-positive patients and 20 were from patients whose regional lymph node status was provided by the biobank as NX.
For reproducibility testing (Figure 2), three sets of serially cut sections, each comprised of one H\&E 4-micron stained slide and three 10-micron thick unstained slides, were prepared from each FFPE block. All cut and slide mounted sections were shipped to NanoString and then one set from each of the 43 blocks was distributed to the appropriate testing site for processing. All 43 specimens were reviewed independently by a separate pathologist for each of the three sites.

For each tissue sample, a test run consisting of macrodissection, RNA extraction, and testing with the Prosigna assay was performed by a single operator at each site following the provided standard operating procedures. Each operator performed a minimum of four test runs consisting of up to 10 tissue samples per run. Each batch of tissue samples required a minimum run time of 3 days from tissue processing to result. Isolated RNA that met the quantity and quality specifications from each of the slide mounted sections was tested twice in separate assay runs. Different lots of RNA isolation kit reagents were used at each site, and a single lot of the Prosigna assay kit was used at all three sites.

The test results for all samples remained blinded to all personnel at all sites until the study was complete. Upon completion of the study the blinded Prosigna assay data were collected from each site and merged with the expected test result and study variables (site, operator, reagent lot, etc.) associated with each unique sample ID. The prospectively defined analysis plan was then executed on the merged analysis dataset.

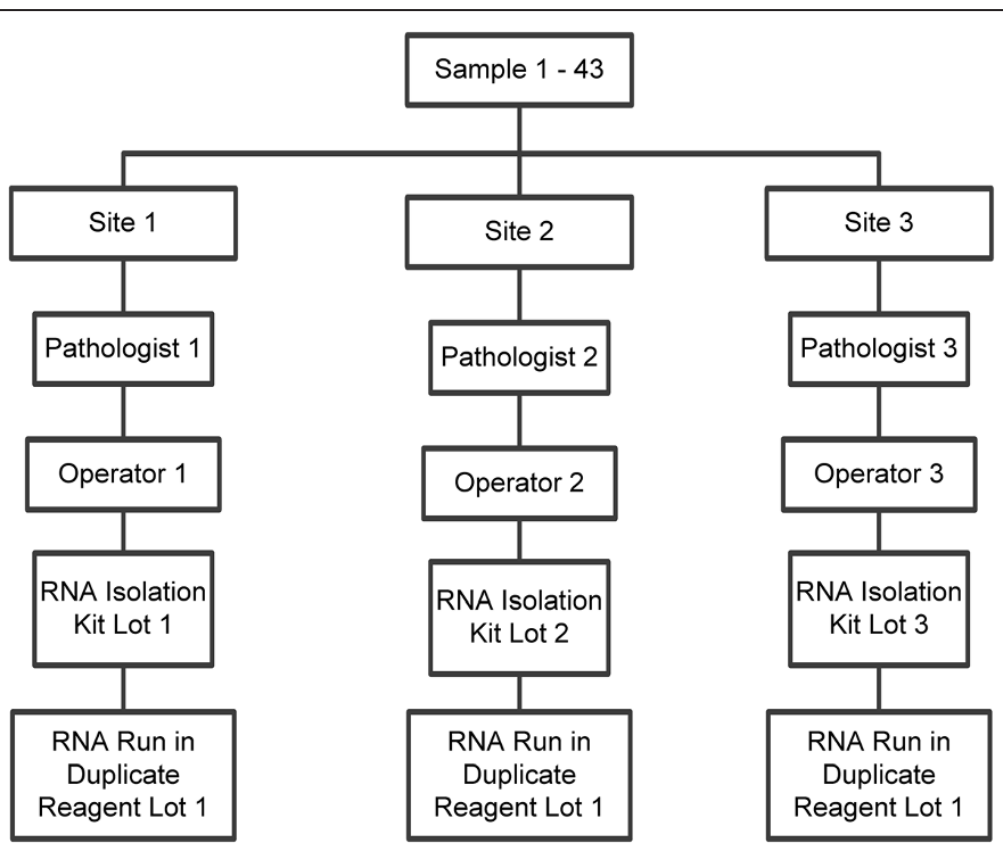

Figure 2 Overview of the design for the tissue reproducibility validation study. Tissue samples (1-43) were processed in parallel across different sites, pathologists, operators, and RNA isolation kits. 


\section{Reproducibility: statistical analysis}

The pre-specified primary aim of the tissue reproducibility validation was to demonstrate the Prosigna assay is highly reproducible, when combining all sources of variation. For this study, "highly reproducible" was defined as a total standard deviation (SD) of less than 4.3 ROR units. The value of $<4.3$ was chosen because if two samples have true ROR scores that differ by 10 units, a total SD of 4.3 means that $95 \%$ of the time the higher of the two will still have a higher individual observed ROR score. A change of 10 ROR units corresponds to an average change in 10-year distant recurrence free survival of $7 \%$ and $6 \%$ for node negative and node positive patients respectively [19].

The following variance components model was used to characterize the sources of variability:

$$
\begin{aligned}
\text { Measurement }= & \text { FFPE Block }+ \text { site }+ \text { tissue section } \\
& + \text { error }
\end{aligned}
$$

where FFPE Block was treated as a fixed component, and site and section were treated as random components. The "site" term measured the systematic sitespecific variation that was constant across all tissue samples (pathologist, technician, extraction kit). The tissue section component measures random variation that differed as a function of review/processing or within FFPE block variation. The error term was derived from the duplicate RNA samples and estimated the combination of run-to-run and within-run variance. Variance components were estimated using the $\mathrm{R}$ procedure "lmer". In the above model, the variance components were estimated from a combined analysis of all FFPE blocks after verifying that were no systematic changes in tissue-specific variation as a function of ROR score.

The tissue and RNA isolation components were estimated using the reproducibility validation and the assay components were estimated using the RNA precision validation. The total variability, $\sigma_{\text {total }}^{2}$, was calculated as:

$$
\sigma_{\text {total }}^{2}=\sigma_{\text {tissue }}^{2}+\sigma_{\text {RNA assay }}^{2}
$$

where $\sigma_{\text {tissue }}^{2}$ was estimated as the sum of the site-to-site and section component estimated in the tissue reproducibility study, and $\sigma_{R N A \text { assay }}^{2}$ was estimated as the total variation from the RNA precision study.

Additional categorical analyses were performed using two classifications:

- 3 risk-categories (low, intermediate, and high) using both the node-negative and node-positive cutoffs,

- 4 intrinsic subtype categories (Luminal A, Luminal B, Basal-Like, HER2-enriched)
RNA from each tissue sample was tested twice at each site so there are 4 possible comparisons between sites for each tissue sample leading to a total number of possible comparisons of $4 \%$ number of tissue samples. For each of the two classification schemes (risk category or subtype), the pair-wise concordance between sites was estimated as the fraction of all possible comparisons that were concordant and an exact-type 95\% confidence interval was calculated.

In addition, a post hoc analysis compared the normalized gene expression from the 50 classifier genes between the tissue replicates from all valid specimens tested at each site using a linear regression and correlation analysis

\section{RNA input: study design}

Thirteen FFPE breast tumor blocks containing pathologicallyconfirmed infiltrating ductal carcinoma were obtained and RNA was extracted from multiple slide mounted tissue sections from each block using the defined procedure (Figure 3). The individual RNA isolates from each FFPE block were pooled. Each pooled tumor RNA sample was tested in duplicate across three RNA input levels within the assay specification range (500, 250, and $125 \mathrm{ng}$ ) and in singlet at two additional RNA input levels outside of the specification range $(625,62.5 \mathrm{ng})$. Two no-target (water) measurements were also tested in duplicate on every run. All tumor RNA samples were assumed to be nodenegative with a tumor size of $\leq 2 \mathrm{~cm}$ for this analytical study since these clinical covariates have no impact on the measured variation in the ROR score. All samples were tested using two different Prosigna assay reagent lots.

\section{RNA input: statistical analysis}

The pre-specified primary aim of the RNA input study was to demonstrate the Prosigna assay results were

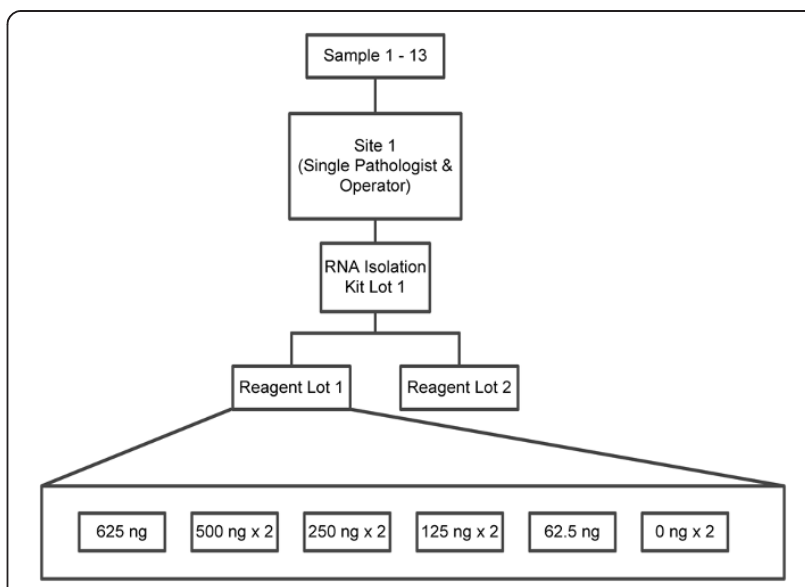

Figure 3 Overview of the design for the RNA input study. RNA from 13 tissue samples was tested across and beyond the RNA input range specified for the assay. 
unchanged at the extremes of the assay specification range (125 and $500 \mathrm{ng}$ RNA) regardless of the assay reagent kit lot used. For each kit lot, the test statistic was the average difference between the mean ROR score at a given input level $\left(\overline{\mathrm{ROR}}_{\mathrm{Lj}}\right)$ and the mean ROR score at the nominal level $\left(\overline{\operatorname{ROR}}_{\mathrm{Nj}}\right)$ :

$$
\text { Average Difference }=\frac{1}{n} \sum_{j=1}^{n}\left(\overline{R O R}_{L j}-\overline{R O R}_{N j}\right)
$$

where the average is across the $\mathrm{n}$ different samples. In this equation, $\overline{\mathrm{ROR}}_{\mathrm{Nj}}$ is the average of two replicates at the nominal level and $\overline{R O R}_{L j} s$ the average of two replicates for input levels within specification, or is the single result for input levels outside of specification. Equivalence was pre-defined as an observed absolute average ROR difference significantly less than 3 . To test the nonequivalence hypothesis that the true absolute mean difference is greater than 3, a 90\% confidence interval for the difference was calculated. This $90 \%$ confidence interval corresponds to the two one-sided test approach for bioequivalence [31]. The input level was determined to be equivalent to the nominal level if the $90 \%$ confidence interval is completely contained within -3 and 3 .

For each pooled sample a linear regression and correlation analysis was also performed between each replicate at each RNA input level and one of the two replicates run at $250 \mathrm{ng}$ of RNA. The difference in the ROR score ( $\triangle \mathrm{ROR}$ ) from the nominal RNA input level $(250 \mathrm{ng}$ ) for each replicate at each RNA input level was calculated by subtracting the ROR score calculated from one of the two replicates run at $250 \mathrm{ng}$ from ROR scores calculated at the other input levels. Additionally, the $\triangle \mathrm{ROR}$ was calculated and linear regression and correlation analyses were also performed between the two replicates at $250 \mathrm{ng}$. The mean $\Delta \mathrm{ROR}$, slope, intercept, and correlation values (with 95\% confidence intervals) were calculated using the pairwise comparisons for all passing samples at each input level for both kit lots.

For the no-target (water) samples, the percentage of samples failing the minimum threshold for expression of normalizing genes was calculated. All no-target samples were required to give a failing test result.

\section{Tissue interferents: study design and analysis}

Twenty three FFPE breast tumor blocks were obtained containing pathologically-confirmed infiltrating ductal carcinoma microscopically-assessed to have $10-95 \%$ of the total tissue area containing normal/non-tumor tissue. Pathologists identified additional tumor interferents (DCIS, necrotic tissue, or blood/hemorrhagic tissue) within or near the margins of the tumor in ten of the 23 blocks.
For each FFPE breast tumor block, H\&E stained slides were prepared and up to nine unstained sections were cut and mounted on slides. For the inclusion of the interferent, the sections were processed according to the assay procedure with the exception that identified nor$\mathrm{mal} /$ non-tumor tissue or any additional interferents were included in the isolation ("non-macrodissected slides"). For the macrodissection where the non-tumor and other interferents were removed, three or (in the case of small tumor surface areas) three and six slides were processed according to the Prosigna assay protocol.

The change in ROR ( $\triangle \mathrm{ROR}$ ) due to the interferent was calculated using the ROR score from the nonmacrodissected slides minus the ROR score from the macrodissected slides (Figure 4). For the tissue blocks where three and six macrodissected slides were independently isolated and both produced a passing assay result, the average of the two ROR scores were used to calculate the $\triangle \mathrm{ROR}$.

\section{Results}

RNA precision: variance components analysis

The precision of the Prosigna assay starting from RNA was assessed with 5 pooled breast tumor RNA samples each tested 36 times at each of the three sites. There were no individual test samples that failed the pre-specified data QC metrics in the software so the analysis includes 540 results from 54 valid runs. For all five tumor RNA samples, the total SD was less than 1 ROR unit on a 0 - 100 scale (Table 2), and there was $100 \%$ concordance between measured subtype result and expected subtype result as well as measured and expected risk group. More than $60 \%$ of the measured variability came from within-run variance (repeatability) while less than $2 \%$ of the variance was attributable to site-to-site variance or operator-to-operator variance. The differences in mean ROR scores between sites were less than 0.5 ROR units on a 0-100 scale and were insignificant for all tested samples (Additional file 1: Table S1). The contribution to overall variance by the three reagent lots was approximately $20 \%$ of the total variance on average, but the differences were all less than 1 ROR unit. At each site, the normalized gene expression between RNA replicates was highly correlated with slopes ranging from $0.98-1.00$, intercepts at 0 , and $\mathrm{r}$ values of 0.99 .

The distribution of measured ROR scores for each of the five pooled RNA samples was also examined across the three lots, six users and three test sites. The range of ROR scores for the 108 independent measurements was $\leq 4$ units for each of the 5 sample pools (Figure 5).

\section{Reproducibility: test sample quality control and characterization}

The call rate for the 43 tissue samples evaluated was $95 \%, 93 \%$, and $100 \%$ for sites 1,2 , and 3 respectively. 


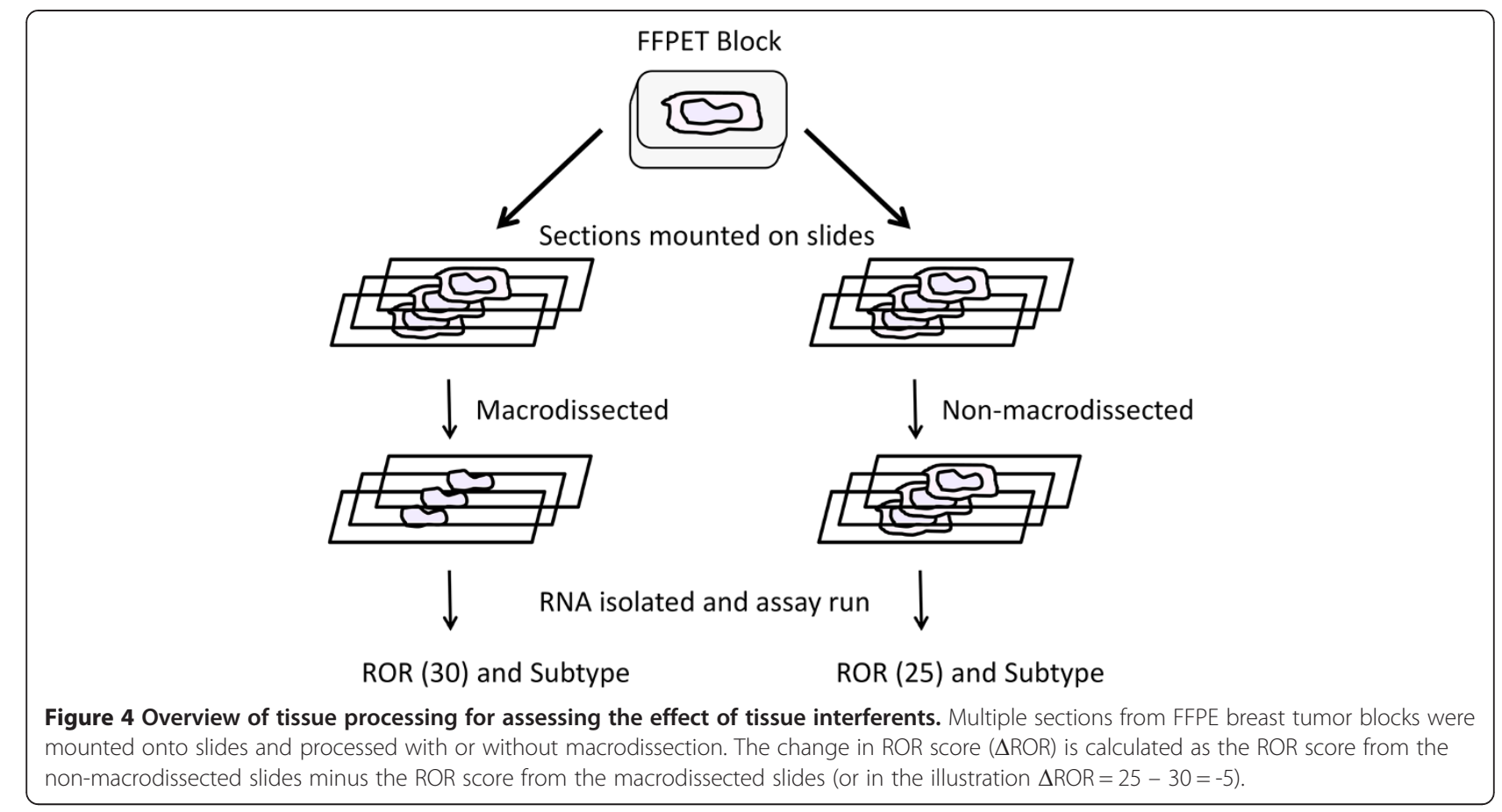

Forty samples yielded results at all sites (RNA isolation of one sample at one site required repeating). One tissue sample yielded results at 2 sites, and 2 samples yielded results at a single site, while the other sites did not obtain sufficient RNA to perform the assay for these samples. The measured tumor surface area for 4/5 RNA isolation failures was very small $\left(\leq 15 \mathrm{~mm}^{2}\right)$. One hundred percent $(100 \%)$ of samples passing tissue review and RNA isolation specifications yielded passing results from the Prosigna assay.

The calculated test results from the 43 tissues across all sites represent a wide range (94 units) of ROR scores (Figure 6) and all risk categories when applying the node-negative or node-positive ROR score cutoffs to all samples. All four intrinsic subtypes were also represented among the 43 specimens. The two samples where RNA could only be successfully isolated at one site were excluded from all subsequent statistical analysis as there was no available data for comparing across sites. Both of these samples had
ROR scores of less than 10 and were classified as Luminal A.

\section{Reproducibility: variance components analysis (primary objective)}

Table 3 shows the results of the variance components analysis using all 41 tissue specimens where replicate measurements were available. The "tissue section" variation, which consists of variation contributed by within FFPE block sections, pathology review, and tissue processing, was the dominant source of variation ( $>90 \%$ of total variance). The differences on average between the sites were negligible ( $<1 \%$ of total variance). The combined run-to-run variability and within-run variability in the assay (determined from the duplicate measurements from each RNA isolation from the reproducibility study) was consistent with the variability measured in the RNA-precision study (variance of 0.51 compared to 0.47 for the RNA-precision study).

The total SD including all source of variation (tissue and RNA processing variability) was 2.9 indicating that

Table 2 Variance components for the five pooled RNA samples across 108 replicates

\begin{tabular}{|c|c|c|c|c|c|c|c|c|}
\hline \multirow{2}{*}{$\begin{array}{c}\text { Pooled RNA } \\
\text { sample }\end{array}$} & \multirow{2}{*}{$\begin{array}{l}\text { Mean ROR } \\
\text { score }\end{array}$} & \multicolumn{5}{|c|}{ Variance component (\%) } & \multirow{2}{*}{$\begin{array}{c}\text { Total } \\
\text { variance }\end{array}$} & \multirow{2}{*}{$\begin{array}{c}\text { Total } \\
\text { SD }\end{array}$} \\
\hline & & Reagent lot & Site & Operator & Run & Within-run & & \\
\hline Basal-like & 55.4 & $0.059(20 \%)$ & $0.000(0 \%)$ & $0.000(0 \%)$ & $0.046(15 \%)$ & $0.194(65 \%)$ & $0.299(100 \%)$ & 0.55 \\
\hline HER2-enriched & 76.2 & $0.165(37 \%)$ & $0.000(0 \%)$ & $0.000(0 \%)$ & $0.000(0 \%)$ & $0.277(63 \%)$ & $0.442(100 \%)$ & 0.66 \\
\hline Luminal A & 31.4 & $0.010(2 \%)$ & $0.000(0 \%)$ & $0.000(0 \%)$ & $0.134(30 \%)$ & $0.296(67 \%)$ & $0.44(100 \%)$ & 0.66 \\
\hline Luminal B 1 & 55.0 & $0.105(18 \%)$ & $0.000(0 \%)$ & $0.000(0 \%)$ & $0.046(8 \%)$ & $0.426(74 \%)$ & $0.576(100 \%)$ & 0.76 \\
\hline Luminal B 2 & 64.8 & $0.119(21 \%)$ & $0.014(2 \%)$ & $0.000(0 \%)$ & $0.064(11 \%)$ & $0.380(66 \%)$ & $0.576(100 \%)$ & 0.76 \\
\hline
\end{tabular}

The percent of total variance is listed below the estimated variance. 


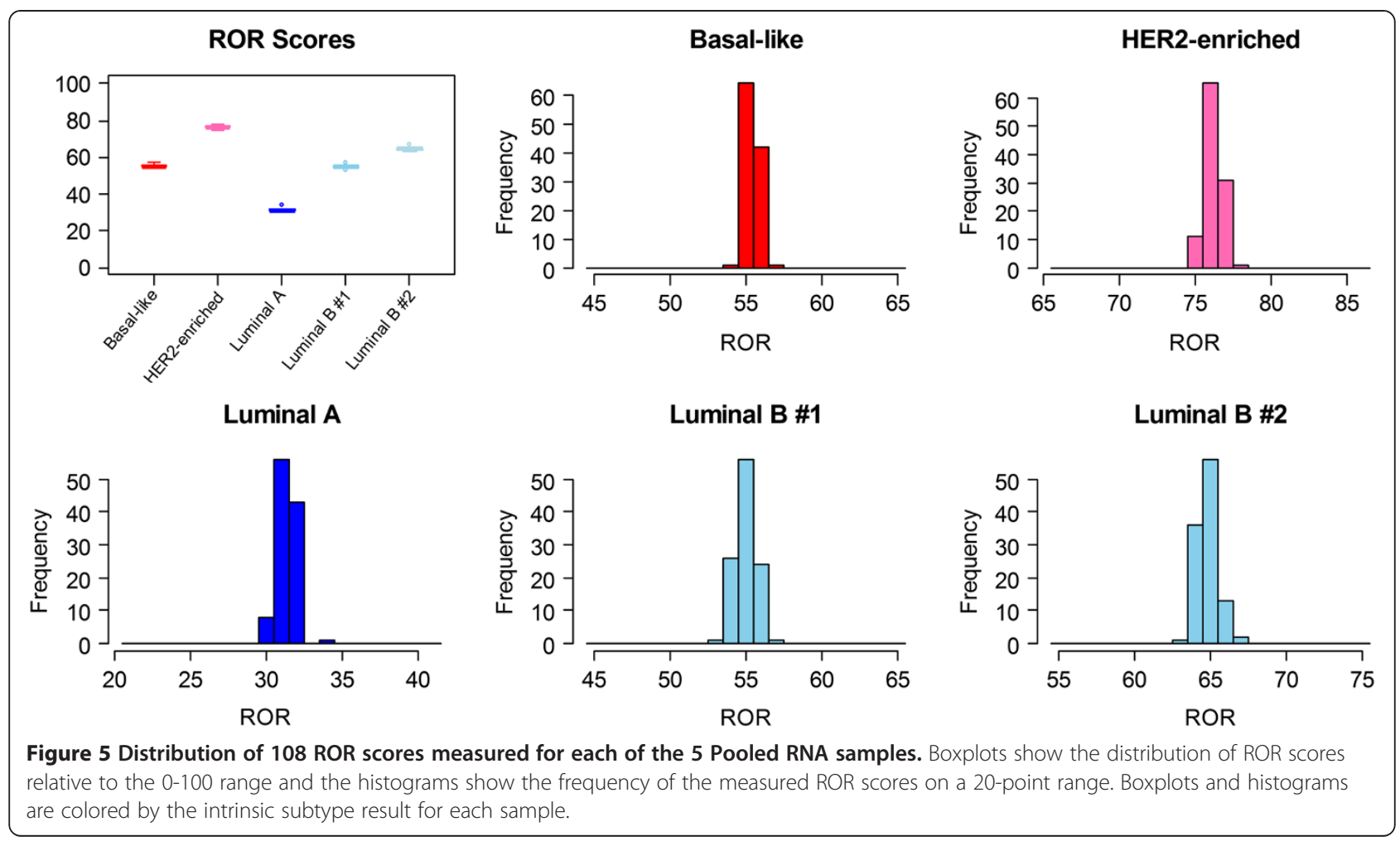

the Prosigna assay can measure a difference between two ROR scores of 6.75 with $95 \%$ confidence.

\section{Reproducibility: subtype and risk category classifications} concordance

The site-to-site concordances for the two categorical classifications are shown in Table 4, in each case with

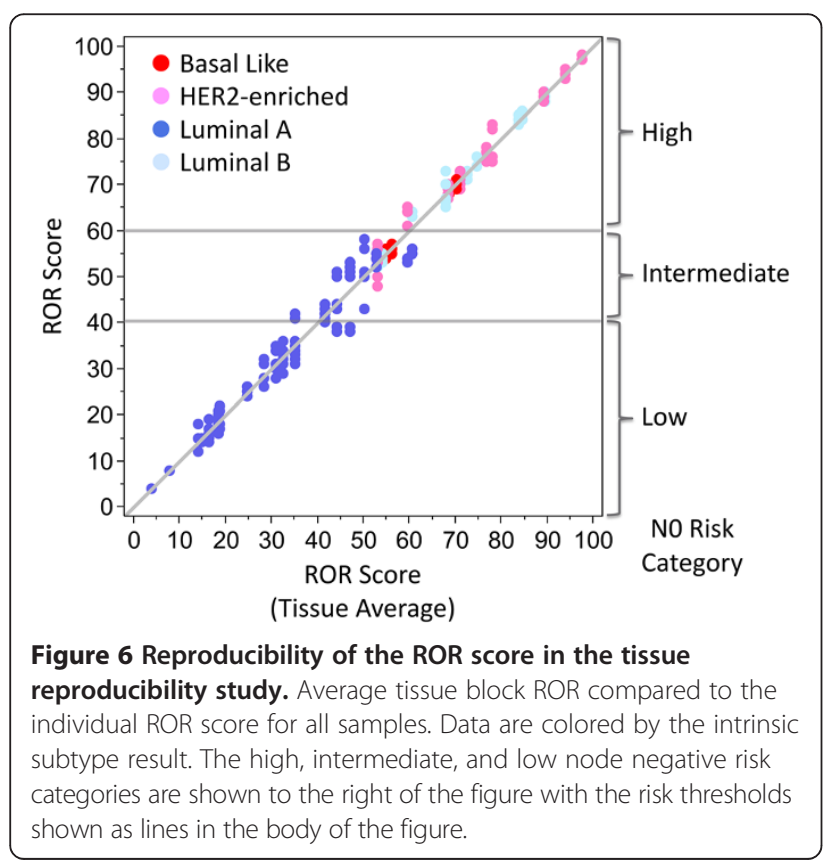

exact-type 95\% confidence intervals. For each comparison (subtype and node negative and positive risk categories), the average concordance between sites was at least $90 \%$. There were no samples where the risk category changed from low risk to high risk (or vice versa) between or within sites when the samples were assumed to be from node negative patients. There were only two intermediate/high risk samples that did not give identical subtypes across all 6 replicates:

- One sample had duplicate Luminal A results at one site and duplicate Luminal B results at each of the other two sites.

- One specimen had duplicate Luminal A results at one site, duplicate HER2-enriched results at another site and one each of Luminal A and HER2-enriched at the third site.

Reproducibility: pairwise correlation coefficients of gene expression

The average intercept, slope, and Pearson's correlation of the pair-wise comparisons between sites are reported

Table 3 Total variability (from tissue and RNA processing) of the Prosigna assay

\begin{tabular}{|c|c|c|c|c|}
\hline \multicolumn{2}{|c|}{ Tissue processing variability } & \multirow{2}{*}{$\begin{array}{l}\text { RNA processing } \\
\text { variability }\end{array}$} & \multirow{2}{*}{$\begin{array}{c}\text { Total } \\
\text { variability }\end{array}$} & \multirow{2}{*}{$\begin{array}{c}\text { Total } \\
\text { SD }\end{array}$} \\
\hline Site & Within block/process & & & \\
\hline 0.10 & 7.72 & 0.47 & 8.29 & 2.9 \\
\hline
\end{tabular}

The total SD of 2.9 is on a $0-100$ ROR scale. 
Table 4 Concordance of subtype calls and risk categories between the three sites

\begin{tabular}{|c|c|c|c|c|}
\hline \multirow{3}{*}{$\begin{array}{c}\text { Comparison } \\
\text { type }\end{array}$} & \multicolumn{3}{|c|}{ Pairwise Concordance $[95 \% \mathrm{Cl}]$} & \multirow{3}{*}{$\begin{array}{c}\text { Average } \\
\text { concordance }\end{array}$} \\
\hline & Site 1 vs. Site 2 & Site 1 vs. Site 3 & Site 2 vs. Site 3 & \\
\hline & $(n=40)$ & $(n=41)$ & $(n=40)$ & \\
\hline \multirow[t]{2}{*}{ Subtype } & $96.3 \%$ & $98.8 \%$ & $95 \%$ & $97 \%$ \\
\hline & {$[86.4 \%-99.5 \%]$} & [91.0\%-100\%] & {$[83.1 \%-99.3 \%]$} & \\
\hline Risk Category & $87.5 \%$ & $92.7 \%$ & $90 \%$ & $90 \%$ \\
\hline (Node Negative) & {$[73.2 \%-95.8 \%]$} & {$[80.1 \%-98.4 \%]$} & {$[76.4 \%-97.2 \%]$} & \\
\hline Risk Category & $90.0 \%$ & $95.1 \%$ & $95.0 \%$ & $93 \%$ \\
\hline (Node Positive) & {$[76.9 \%-96.0 \%]$} & {$[83.9 \%-98.7 \%]$} & {$[83.5 \%-98.6 \%]$} & \\
\hline
\end{tabular}

The pairwise (site to site) concordance is reported with the $95 \%$ confidence interval.

with the 95\% confidence interval (Table 5). The gene expression between tissue replicates was highly correlated between sites with slopes ranging from $0.97-1.00$, intercepts at 0 , and $r$ values of 0.98 or greater. Equivalent or higher correlation values were observed when a similar analysis was performed for the RNA replicates tested at each site (Additional file 2: Table S2). Additionally, hierarchical clustering analysis demonstrated that tissue sample and RNA sample replicates were always and only clustered together across a wide range of expression in each of the 50 genes across all samples tested (Additional file 3: Figure S1).

\section{RNA input: test sample quality control}

The average ROR score for the tested samples covered a broad range $(20-82)$ and all intrinsic subtypes - including 5 Luminal A, 4 Luminal B, 3 HER2-enriched and 1 Basal-like sample (Additional file 4: FigureS2). One FFPE block was tested with a single kit lot due to insufficient RNA mass from the isolation for the second lot. Two runs (each with different samples) failed to provide passing results for one of the two lots tested due to a processing error detected by system controls with

Table 5 Site to site gene expression comparisons from the tissue reproducibility study

\begin{tabular}{|c|c|c|c|c|}
\hline Comparison & Pairwise (n) & $\begin{array}{l}\text { Intercept } \\
{[95 \% \mathrm{Cl}]}\end{array}$ & $\begin{array}{c}\text { Slope } \\
{[95 \% \mathrm{Cl}]}\end{array}$ & $\begin{array}{l}\text { Pearson } \\
{[95 \% \mathrm{Cl}]}\end{array}$ \\
\hline \multirow[t]{2}{*}{ All Sites } & 121 & 0.00 & 0.98 & 0.98 \\
\hline & & {$[-0.01-0.01]$} & [0.97-0.99] & [0.98-0.98] \\
\hline \multirow[t]{2}{*}{ Site 1 vs. Site 2} & 40 & 0.00 & 0.97 & 0.98 \\
\hline & & {$[-0.01-0.01]$} & [0.95-0.98] & [0.97-0.98] \\
\hline \multirow[t]{2}{*}{ Site 1 vs. Site 3} & 40 & 0.01 & 1.00 & 0.98 \\
\hline & & {$[0-0.02]$} & [0.98-1.01] & [0.98-0.99] \\
\hline \multirow[t]{2}{*}{ Site 2 vs. Site 3} & 41 & -0.01 & 0.99 & 0.99 \\
\hline & & {$[-0.02-0]$} & [0.97-1] & [0.98-0.99] \\
\hline
\end{tabular}

Pairwise correlations, slopes, and intercepts of normalized 50 genes for tissues replicates from the tissue reproducibility study. The average intercept, slope, and Pearson's correlation of the pair-wise comparisons are reported with their $95 \%$ confidence intervals. insufficient RNA to repeat the assay. All measured notarget samples $(n=46)$ were well below the threshold for signal and yielded a failing test result $(0 \%$ call rate). All tumor RNA measurements within assay specification $(\mathrm{n}=$ 138 ) yielded a passing test result ( $100 \%$ call rate). One hundred percent $(100 \%)$ of specimens with input above specification $(625 \mathrm{ng})$ yielded a passing test result. Eightythree percent $(83 \%)$ of specimens $(10 / 12)$ tested at input below specification $(62.5 \mathrm{ng})$ yielded a test result in lot 1 , as did $100 \%$ in lot 2 .

\section{RNA input: ROR score difference and pairwise correlation coefficients of gene expression}

For each of the two reagent lots tested, the confidence interval around the mean ROR score difference between the nominal input and the RNA input limits (125 and $500 \mathrm{ng}$ ) were completely contained within -3 and 3 ROR units. The ROR scores at 125 and 500 ng RNA were therefore equivalent to those at the target input concentration of $250 \mathrm{ng}$ for each of the two reagent kit lots tested meeting the primary objective of the study. Of note, when characterizing the RNA levels outside of the assay specification, the ROR scores at 62.5 ng RNA were not equivalent (with an upper confidence limit at 3.26) to those at the target input concentration of $250 \mathrm{ng}$ for one of the two lots tested. This illustrates the importance of performing the assay according to the defined procedure.

When the lots were combined the normalized gene expression values and ROR scores were consistent to those at the target input concentration of $250 \mathrm{ng}$ within and even outside the RNA input limit specifications (Table 6). Characterization of intrinsic subtype across the samples tested shows a $100 \%$ concordance in subtype call across all samples and inputs. Similarly, there is a $100 \%$ concordance by risk classification across all samples and inputs.

Tissue interferents: test sample quality control

Out of 23 samples six were Luminal A, seven were Luminal B, two were HER2-enriched, and eight were Basallike. The average ROR score for the 23 samples covered a broad range (10 - 83), (Additional file 5: Figure S3). 
Table 6 Comparison of gene expression at different masses from the RNA input study

\begin{tabular}{cccccc}
\hline Mass (ng) & Pairwise $(\mathbf{n})$ & $\begin{array}{c}\text { Pearson } \\
{[95 \% \mathrm{Cl}]}\end{array}$ & $\begin{array}{c}\text { Slope } \\
{[95 \% \mathrm{Cl}]}\end{array}$ & $\begin{array}{c}\text { Intercept } \\
{[95 \% \mathrm{Cl}]}\end{array}$ & $\begin{array}{c}\Delta R O R \\
{[95 \% \mathrm{Cl}]}\end{array}$ \\
\hline 62.5 & 21 & $0.97[0.93-0.99]$ & $0.96[0.91-1.00]$ & $-0.02[-0.05-0.01]$ & $0.48[-1.27-2.22]$ \\
125 & 46 & $0.99[0.97-0.99]$ & $0.98[0.96-1.01]$ & $-0.01[-0.03-0.01]$ & $-0.04[-0.89-0.8]$ \\
250 & 23 & $0.99[0.98-1.00]$ & $1.00[0.99-1.01]$ & $0.00[-0.01-0.01]$ & $-0.39[-0.96-0.17]$ \\
500 & 46 & $0.99[0.99-1.00]$ & $0.97[0.96-0.99]$ & $0.02[0.01-0.04]$ & $-0.57[-1.39-0.26]$ \\
625 & 23 & $0.99[0.98-1.00]$ & $0.95[0.92-0.99]$ & $0.03[0.01-0.06]$ & $-0.78[-2.2-0.63]$ \\
\hline
\end{tabular}

Pairwise correlations, slopes, and intercepts of normalized 50 genes and change in ROR score for replicate RNA Hybridizations with different mass inputs. The average intercept, slope, Pearson's correlation, and change in ROR for the pair-wise comparisons are reported with their $95 \%$ confidence intervals.

\section{Tissue interferents: impact on ROR score}

As the amount of adjacent non-tumor tissue increases there is an increasing risk that the reported ROR score will be an underestimate or negatively biased (up to -19 ROR score units for samples containing 95\% non-tumor tissue) estimate of a patient's risk of recurrence (Figure 7). Elimination of the macrodissection step required by the assay also caused a change in subtype determination for five out of 23 samples. Three Luminal B samples, one HER2-enriched, and one basal-like sample were classified as Luminal A due to inclusion of adjacent non-tumor tissue. In contrast, the presence of intratumor hemorrhage, necrosis or DCIS (not removed by macrodissection) had little effect on ROR.

\section{Discussion}

Breast cancer gene expression testing has been the subject of many studies demonstrating its capacity to stratify breast cancers by prognostic risk [9,15,16,32,33]. Increasingly, studies are also showing the value of such signatures to predict response to therapy, for example by using these tests to evaluate archival specimens from randomized clinical trials [34-36]. The integration of molecular genomic testing into cancer care is an active area of development, with huge genomic datasets becoming available. Great improvements in experimental design and bioinformatic analysis have led to the development of robust signatures ripe for translation into clinical tests. Studies applying these signatures to different clinical series with observational, case-control, cohort and randomized trial designs have generated increasingly strong evidence for clinical validity, particularly in breast cancer $[19,34,35,37]$. It is in this backdrop that the Evaluation of Genomic Applications in Practice and Prevention (EGAPP) working group was formed to guide best practices in experimental design and the interpretation of evidence for utility in clinical practice [23]. Fundamental to EGAPP criteria is the concept that clinical utility requires not only clinical validity (linking test results to clinical presentation, treatment and outcome), but just as importantly, analytical validity (the capacity of the test classifier to be sensitive, specific and reproducible in practice). However, EGAPP found that relatively few studies of breast cancer molecular classifiers have directly reported on analytical reproducibility [38].

Analytical reproducibility is a requirement for the implementation of all diagnostic tests, but it is especially critical for decentralized tests given the challenges of maintaining reproducibility across pathologists, technical operators, and instrumentation. However, decentralized tests also have many advantages over Laboratory Developed Tests that are performed at single central laboratories. By avoiding the need for shipping tissues, turnaround times and costs are reduced. The capacity for the laboratory physician to interact directly with the treating physician greatly aids medical care, for example in facilitating appropriate prioritization of critical specimens,

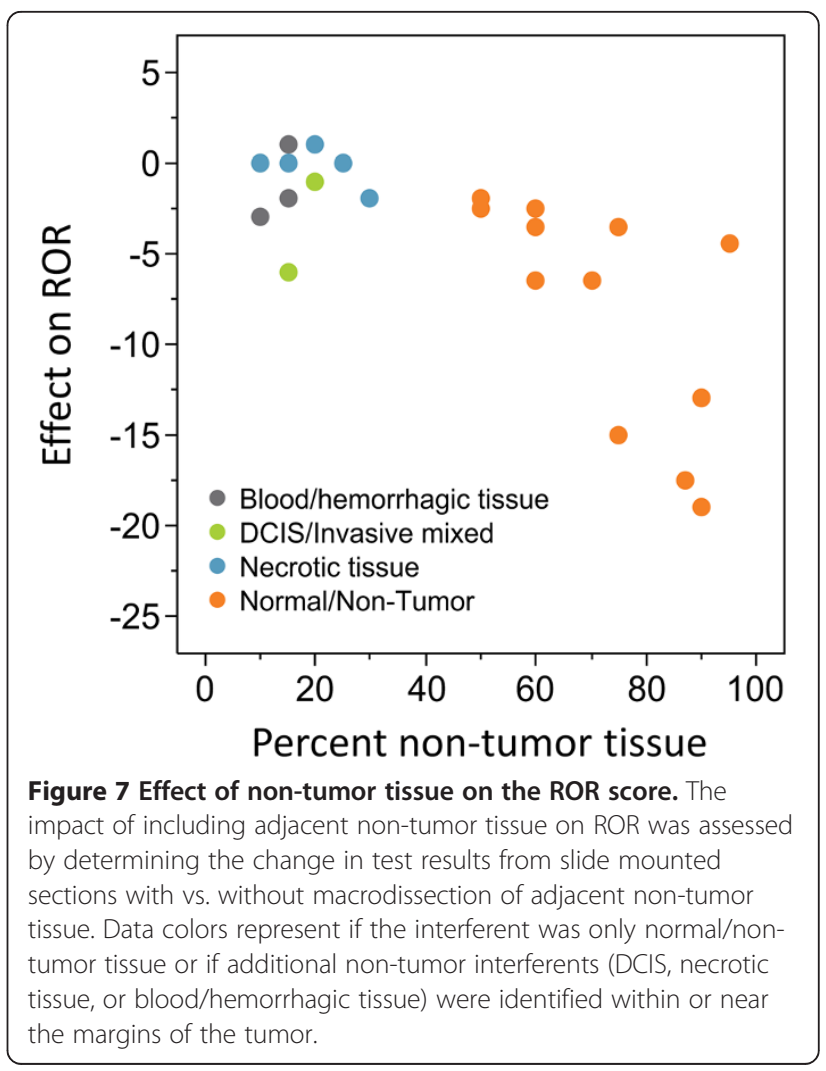


explaining equivocal or unexpected results, and quickly recognizing inadequate specimens and what can be done to get a result helpful to the patient as soon as possible. Although first generation breast cancer prognostic tests were performed in central labs [32], second generation tests are being developed and validated to realize the advantages of decentralized testing [39].

The Prosigna assay was tested across a range of RNA mass inputs that is consistent with what will be expected in a clinical lab setting. The assay is robust across that range, similar to what has been reported with other multigene breast cancer tests [32,39]. Additionally, the assay gave consistent results outside the specified assay RNA input limits; only 2 samples failed to produce passing results at half the lowest specified mass further illustrating the robustness of the assay.

The observation of biased subtype calls and ROR scores with the inclusion of non-tumor tissue is consistent with a prior study [40], however the bias reported herein is less severe. Similar to what is expected to be experienced in clinical practice, the interferent being measured here is reported as percent adjacent non-tumor tissue included, rather than percent non-tumor RNA from a separate paired normal tissue sample reported in the earlier study. Normal breast tissue yields less total RNA compared to tumor tissue [41] and adjacent non-tumor tissue at the margins of the tumor have certain cancer pathways activated where matched healthy breast does not $[42,43]$. Nonetheless, this study illustrates the importance of performing the macrodissection according to the defined procedure to maximize the accuracy of the test.

The precision and reproducibility of the Prosigna assay, estimated from repeat measurements of pooled tumor RNA sample(s) and de-identified patient tissue samples across multiple testing sites is similar (relative to the overall test range) to what was previously reported for centralized lab tests [32,38]. These results demonstrate that the Prosigna assay is analytically reproducible even when performed at multiple test sites and including all process variables. It will be important for local labs to verify the reproducibility reported herein when implementing this decentralized assay to ensure the quality of the test's results, including ongoing process monitoring [38].

Our experience of implementing the nCounter platform in our CLIA-certified hospital laboratory environments proved to be straightforward, confirming the simplicity of the assay and its suitability as an in vitro diagnostic test. Training of the assay workflow (including tissue macrodissection, RNA isolation and setup of Prosigna assay) takes less than one week. The prespecified SOPs are easy to follow and the procedure of RNA extraction and Prosigna assay are straightforward. All operators, most of whom were naïve users to the
Prosigna assay, were able to pass the training procedures on the first attempt, before executing the pre-specified study protocols. Although overnight incubations are required during RNA extraction and RNA - probe hybridization, the incubation temperature is constant, and hands-on time requirements for the whole experiment are very limited. Furthermore, the analyses for subtype call and ROR score are simplified and controlled by integrating the algorithm into the software for raw data processing, reducing the potential for human error in data cleaning and analysis.

\section{Conclusion}

The FDA cleared and CE marked Prosigna assay based on the PAM50 gene expression signature has recently been shown to predict the risk of distant recurrence in women with hormone receptor positive early stage breast cancer treated with five years of endocrine therapy $[19,20]$. This demonstration of analytical reproducibility generates a strong body of evidence supporting the decentralized use of this test as a tool for breast cancer risk stratification. Additional ongoing studies of the clinical validity of the PAM50 gene expression signature for chemosensitivity prediction [34-36] could, if confirmed, be considered clinically actionable given the demonstrated analytical validity of this test.

\section{Additional files}

Additional file 1: Table S1. Site to site ROR sample means. Mean ROR scores were calculated for each pooled RNA sample, and likelihood ratio test for significance was performed to test for differences between sites. There were no significant differences in the results observed across sites for the five pooled RNA samples tested. All p-values were well above 0.05 for the likelihood ratio test of significance of site with 2 degrees of freedom for each pooled RNA sample. The differences in means between sites were all less than 0.5 ROR units on a 0-100 scale.

Additional file 2: Table S2. Within site gene expression comparisons from the tissue reproducibility study. Pairwise correlations, slopes, and intercepts of normalized 50 genes for replicate RNA Hybridizations from the tissue reproducibility study. The average intercept, slope, and Pearson's correlation of the pair-wise comparisons are reported with the 95\% confidence interval.

Additional file 3: Figure S1. Hierarchical clustering of all samples from the tissue reproducibility study. Clustering analysis (using a Pearson's distance metric and average linkage) was performed on the median centered normalized, Log2 transformed and scaled sample data to further characterize the gene expression in the tissue samples. The tissue sample and RNA sample replicates were always only clustered together and the node heights are almost imperceptibly low (indicating highly correlated gene expression).

Additional file 4: Figure S2. Average ROR Score for the 13 unique tumor RNA samples within the RNA Input Study. Data are colored by the intrinsic subtype result at $250 \mathrm{ng}$ of RNA.

Additional file 5: Figure S3. ROR Score for the 23 unique macrodissected tumor samples. Data are colored by the intrinsic subtype result for each tissue. For tissues with multiple isolations the subtype result illustrated was from the macrodissection with the most number of slides processed. 


\section{Abbreviations}

ROR: Risk of recurrence; SD: Standard deviation; FDA: US Food and Drug Administration; CLSI: Clinical Laboratory and Standards Institute; EGAPP: Evaluation of genomic applications in practice and prevention; FFPE: Formalin-fixed paraffin-embedded.

\section{Competing interests}

TN disclosed that he is one of the holders of the patents on which the Prosigna Assay is based and is a co-founder of Bioclassifier, LLC which licenses the PAM50 algorithm to NanoString Technologies, Inc. JS, SF, BW, $N D$, and MM all disclose that they are employees of and shareholders in NanoString Technologies. CS is a paid consultant of NanoString Technologies, Inc. All other authors had no disclosures to report.

\section{Author's contributions}

TN, JS, BW, CS, SF, SL contributed to the study design and protocols and drafted the manuscript. CS, JS, and BW performed statistical analysis and presentation of data. DG performed tissue review for the tissue reproducibility study and the tissue interference study. ND, MM, and GB performed the assay for the RNA precision study. ND and GB performed the assay for the tissue reproducibility study. ND performed the assay for the RNA input and tissue interferents studies. All authors read and approved the final manuscript.

\section{Acknowledgments}

We thank Sandra McDonald, MD from Washington University School of Medicine for her excellent work in procuring, maintaining the integrity and de-identification, and histological review of tissue specimens for the tissue reproducibility study.

We thank Shashikant Kulkarni PhD, FACMG, Vishwanathan Hucthagowder $\mathrm{PhD}$, and Mike Evenson for providing laboratory space, technical expertise, and execution of tissue reproducibility and RNA precision protocols. We thank Katherine Deschryver, MD from Washington University School of Medicine for her histological review of tissue specimens for the tissue reproducibility study.

We thank Nasrin Mawji from the Centre for Translational and Applied Genomics at BC Cancer Agency for her work in executing the RNA precision protocol.

\section{Author details}

${ }^{1}$ British Columbia Cancer Agency, 3427 - 600 W 10TH Avenue, V5Z 4E6 Vancouver, BC, Canada. ${ }^{2}$ NanoString Technologies, Inc., 530 Fairview Avenue North, Suite 2000, Seattle, WA, USA. ${ }^{3}$ Myraqa, 3 Lagoon Drive, Redwood Shores, CA, USA. ${ }^{4}$ Anatomical Pathology JPN 1401, Vancouver Hospital, 855 W. 12th Ave, V5Z 1 M9 Vancouver, BC, Canada.

\section{Received: 24 October 2013 Accepted: 12 February 2014}

Published: 13 March 2014

\section{References}

1. Henry NL, Hayes DF: Cancer biomarkers. Mol Oncol 2012, 6(2):140-146.

2. Dietel M, Johrens $K$, Laffert M, Hummel M, Blaker H, Muller BM, Lehmann A, Denkert C, Heppner FL, Koch A, Sers C, Anagnostopoulos I: Predictive molecular pathology and its role in targeted cancer therapy: a review focussing on clinical relevance. Cancer Gene Ther 2013, 20(4):211-221.

3. Duffy MJ, Crown J: Companion Biomarkers: Paving the Pathway to Personalized Treatment for Cancer. Clin Chem 2013, 59(10):1447-1456.

4. Gown AM: Current issues in ER and HER2 testing by IHC in breast cancer. Mod Pathol 2008, 21(Suppl 2):S8-S15.

5. Wolff AC, Hammond ME, Schwartz JN, Hagerty KL, Allred DC, Cote RJ, Dowsett M, Fitzgibbons PL, Hanna WM, Langer A, McShane LM, Paik S, Pegram MD, Perez EA, Press MF, Rhodes A, Sturgeon C, Taube SE, Tubbs R, Vance GH, van de Vijver M, Wheeler TM, Hayes DF, American Society of Clinical Oncology, College of American Pathologists: American Society of Clinical Oncology/College of American Pathologists guideline recommendations for human epidermal growth factor receptor 2 testing in breast cancer. J Clin Oncol 2007, 25(1):118-145.

6. Sholl LM, Xiao Y, Joshi $V$, Yeap BY, Cioffredi LA, Jackman DM, Lee $C$, Janne PA, Lindeman NI: EGFR mutation is a better predictor of response to tyrosine kinase inhibitors in non-small cell lung carcinoma than FISH, CISH, and immunohistochemistry. Am J Clin Pathol 2010, 133(6):922-934.
7. Weichert W, Schewe C, Lehmann A, Sers C, Denkert C, Budczies J, Stenzinger A, Joos H, Landt O, Heiser V, Rocken C, Dietel M: KRAS genotyping of paraffin-embedded colorectal cancer tissue in routine diagnostics: comparison of methods and impact of histology. $J \mathrm{Mol}$ Diagn 2010, 12(1):35-42.

8. Perou CM, Sorlie T, Eisen MB, van de Rijn M, Jeffrey SS, Rees CA, Pollack JR, Ross DT, Johnsen $H$, Akslen LA, Fluge O, Pergamenschikov A, Williams C, Zhu SX, Lonning PE, Borresen-Dale AL, Brown PO, Botstein D: Molecular portraits of human breast tumours. Nature 2000, 406(6797):747-752.

9. Paik S, Shak S, Tang G, Kim C, Baker J, Cronin M, Baehner FL, Walker MG Watson D, Park T, Hiller W, Fisher ER, Wickerham DL, Bryant J, Wolmark N: A multigene assay to predict recurrence of tamoxifen-treated, nodenegative breast cancer. N Engl J Med 2004, 351(27):2817-2826.

10. van de Vijver MJ, He YD, van't Veer LJ, Dai H, Hart AA, Voskuil DW, Schreiber GJ, Peterse JL, Roberts C, Marton MJ, Parrish M, Atsma D, Witteveen A, Glas A, Delahaye L, van der Velde T, Bartelink H, Rodenhuis S, Rutgers ET, Friend $\mathrm{SH}$, Bernards R: A gene-expression signature as a predictor of survival in breast cancer. N Engl J Med 2002, 347(25):1999-2009.

11. Arpino G, Generali D, Sapino A, Del Lucia M, Frassoldati A, De Laurentis M, Paolo P, Mustacchi G, Cazzaniga M, De Placido S, Conte P, Cappelletti M, Zanoni V, Antonelli A, Martinotti M, Puglisi F, Berruti A, Bottini A, Dogliotti L: Gene expression profiling in breast cancer: a clinical perspective. Breast 2013, 22(2):109-120.

12. Harris L, Fritsche $H$, Mennel R, Norton L, Ravdin P, Taube S, Somerfield MR, Hayes DF, Bast RC Jr, American Society of Clinical Oncology: American Society of Clinical Oncology 2007 update of recommendations for the use of tumor markers in breast cancer. J Clin Oncol 2007, 25(33):5287-5312.

13. Zujewski JA, Kamin L: Trial assessing individualized options for treatment for breast cancer: the TAILORx trial. Future Oncol 2008, 4(5):603-610.

14. Cardoso F, Van't Veer L, Rutgers E, Loi S, Mook S, Piccart-Gebhart MJ: Clinical application of the 70-gene profile: the MINDACT trial. J Clin Oncol 2008, 26(5):729-735

15. Parker JS, Mullins M, Cheang MC, Leung S, Voduc D, Vickery T, Davies S, Fauron C, He X, Hu Z, Quackenbush JF, Stijleman IJ, Palazzo J, Marron JS, Nobel AB, Mardis E, Nielsen TO, Ellis MJ, Perou CM, Bernard PS: Supervised risk predictor of breast cancer based on intrinsic subtypes. J Clin Oncol 2009, 27(8):1160-1167.

16. Nielsen TO, Parker JS, Leung $S$, Voduc D, Ebbert M, Vickery T, Davies SR, Snider J, Stijleman IJ, Reed J, Cheang MC, Mardis ER, Perou CM, Bernard PS, Ellis MJ: A comparison of PAM50 intrinsic subtyping with immunohistochemistry and clinical prognostic factors in tamoxifen-treated estrogen receptor-positive breast cancer. Clin Cancer Res 2010, 16(21):5222-5232.

17. Geiss GK, Bumgarner RE, Birditt B, Dahl T, Dowidar N, Dunaway DL, Fell HP, Ferree S, George RD, Grogan T, James JJ, Maysuria M, Mitton JD, Oliveri P, Osborn JL, Peng T, Ratcliffe AL, Webster PJ, Davidson EH, Hood L, Dimitrov K: Direct multiplexed measurement of gene expression with color-coded probe pairs. Nat Biotechnol 2008, 26(3):317-325.

18. Reis PP, Waldron L, Goswami RS, Xu W, Xuan Y, Perez-Ordonez B, Gullane P, Irish J, Jurisica I, Kamel-Reid S: mRNA transcript quantification in archival samples using multiplexed, color-coded probes. BMC Biotechnol 2011, 11:46-6750. 11-46.

19. Dowsett M, Sestak I, Lopez-Knowles E, Sidhu K, Dunbier AK, Cowens JW, Ferree S, Storhoff J, Schaper C, Cuzick J: Comparison of PAM50 Risk of Recurrence Score With Oncotype DX and IHC4 for Predicting Risk of Distant Recurrence After Endocrine Therapy. J Clin Oncol 2013. 31(22):2783-2790.

20. Gnant M, Filipits M, Mlineritsch B, Dubsky P, Jakesz R, Kwasny W, Fitzal F, Rudas M, Knauer M, Singer C, Greil R, Ferree S, Storhoff J, Cowens J, Schaper C, Liu S, Nielsen T: Clinical validation of the PAM50 risk of recurrence (ROR) score for predicting residual risk of distant-recurrence (DR) after endocrine therapy in postmenopausal women with $E R+$ early breast cancer (EBC): An ABCSG study [abstract]. Cancer Res 2012, 72(24):P2-10-02.

21. Gnant M, Filipits M, Dubsky P, Rudas M, Balic M, Greil R, Ferree S, Cowens J, Schaper C, Nielsen T: 530 PR Predicting risk for late metastasis: The PAM50 risk of recurrence (ROR) score after 5 years of endocrine therapy in postmenopausal women with $\mathrm{HR}+$ early breast cancer: A study on 1,478 patients from the ABCSG-8 trial [abstract]. Ann Oncol 2013, 24(3):29. doi:10.1093/annonc/mdt084.1

22. Simon RM, Paik S, Hayes DF: Use of archived specimens in evaluation of prognostic and predictive biomarkers. J Natl Cancer Inst 2009, 101(21):1446-1452 
23. Teutsch SM, Bradley LA, Palomaki GE, Haddow JE, Piper M, Calonge N, Dotson WD, Douglas MP, Berg AO, EGAPP Working Group: The Evaluation of Genomic Applications in Practice and Prevention (EGAPP) Initiative: methods of the EGAPP Working Group. Genet Med 2009, 11(1):3-14.

24. Gnant M, Dowsett M, Filipits M, Lopez-Knowles E, Greil R, Balic M, Cowens J, Nielsen T, Shaper C, Sestak I, Fesl C, Cuzick J: Identifying clinically relevant prognostic subgroups in node-positive postmenopausal HR + early breast cancer patients treated with endocrine therapy: A combined analysis of 2,485 patients from ABCSG-8 and ATAC using the PAM50 risk of recurrence (ROR) score and intrinsic subtype [abstract]. J Clin Oncol 2013, 31:506.

25. Tholen D, Kallner A, Kennedy J, Krouwer J, Meier K: Clinical and Laboratory Standards Institute (CLSI). Evaluation of precision performance of quantitative measurement methods; approved guideline - second edition. CLSI document EP05-A2. 950 west valley road, suite 2500. Wayne, PA, USA: CLSI; 2004.

26. NanoString Technologies Inc: Prosigna ${ }^{\text {TM }}$ Breast Cancer Prognostic Gene Signature Assay [Package Insert]. Seattle, WA: NanoString Technologies, Inc; 2013.

27. Majidzadeh-A K, Esmaeili R, Abdoli N: TFRC and ACTB as the best reference genes to quantify Urokinase Plasminogen Activator in breast cancer. BMC Res Notes 2011, 4:215-0500. 4-215.

28. Szabo A, Perou CM, Karaca M, Perreard L, Palais R, Quackenbush JF, Bernard PS: Statistical modeling for selecting housekeeper genes. Genome Biol 2004, 5(8):R59.

29. Baker SC, Bauer SR, Beyer RP, Brenton JD, Bromley B, Burrill J, Causton H, Conley MP, Elespuru R, Fero M, Foy C, Fuscoe J, Gao X, Gerhold DL, Gilles P, Goodsaid F, Guo X, Hackett J, Hockett RD, Ikonomi P, Irizarry RA, Kawasaki ES, Kaysser-Kranich T, Kerr K, Kiser G, Koch WH, Lee KY, Liu C, Liu ZL, Lucas A, Manohar CF, Miyada G, Modrusan Z, Parkes H, Puri RK, Reid L, Ryder TB, Salit M, Samaha RR, Scherf U, Sendera TJ, Setterquist RA, Shi L, Shippy R, Soriano JV, Wagar EA, Warrington JA, Williams M, Wilmer F, Wilson M, Wolber PK, Wu X, Zadro R, External RNA Controls Consortium: The External RNA Controls Consortium: a progress report. Nat Methods 2005, 2(10):731-734.

30. Warrington J, Corbisier P, Feilotter H, Hackett J, Reid L, Salit M, Wagar E, Williams P, Wolber P: Clinical and Laboratory Standards Institute (CLSI). Use of External RNA Controls in Gene Expression Assays; Approved Guideline. CLSI Document MM16-A. 940 west valley road, suite 1400. Wayne, PA, USA: CLSI; 2006.

31. Berger R, Hsu J: Bioequivalence trials, intersection-union tests and equivalence confidence sets. Stat Sci 1996, 11:283-319.

32. Cronin M, Sangli C, Liu ML, Pho M, Dutta D, Nguyen A, Jeong J, Wu J, Langone KC, Watson D: Analytical validation of the Oncotype DX genomic diagnostic test for recurrence prognosis and therapeutic response prediction in node-negative, estrogen receptor-positive breast cancer. Clin Chem 2007, 53(6):1084-1091.

33. Nuyten DS, Hastie T, Chi JT, Chang HY, van de Vijver MJ: Combining biological gene expression signatures in predicting outcome in breast cancer: An alternative to supervised classification. Eur J Cancer 2008, 44(15):2319-2329.

34. Chia SK, Bramwell VH, Tu D, Shepherd LE, Jiang S, Vickery T, Mardis E, Leung S, Ung K, Pritchard Kl, Parker JS, Bernard PS, Perou CM, Ellis MJ, Nielsen TO: A 50-gene intrinsic subtype classifier for prognosis and prediction of benefit from adjuvant tamoxifen. Clin Cancer Res 2012, 18(16):4465-4472.

35. Cheang MC, Voduc KD, Tu D, Jiang S, Leung S, Chia SK, Shepherd LE, Levine MN, Pritchard KI, Davies S, Stijleman IJ, Davis C, Ebbert MT, Parker JS, Ellis MJ, Bernard PS, Perou CM, Nielsen TO: Responsiveness of intrinsic subtypes to adjuvant anthracycline substitution in the NCIC.CTG MA.5 randomized trial. Clin Cancer Res 2012, 18(8):2402-2412.

36. Jorgensen C, Nielsen T, Bjerre K, Liu S, Wallden B, Balslev E, Nielsen D, Ejlertsen B: PAM50 breast cancer intrinsic subtypes and effect of gemcitabine in advanced breast cancer patients. Acta Oncol 2013.

37. Filipits M, Rudas M, Jakesz R, Dubsky P, Fitzal F, Singer CF, Dietze O, Greil R, Jelen A, Sevelda P, Freibauer C, Muller V, Janicke F, Schmidt M, Kolbl H, Rody A, Kaufmann M, Schroth W, Brauch H, Schwab M, Fritz P, Weber KE, Feder IS, Hennig G, Kronenwett R, Gehrmann M, Gnant M, EP Investigators: A new molecular predictor of distant recurrence in ER-positive, HER2negative breast cancer adds independent information to conventional clinical risk factors. Clin Cancer Res 2011, 17(18):6012-6020.

38. Evaluation of Genomic Applications in Practice and Prevention (EGAPP) Working Group: Recommendations from the EGAPP Working Group: can tumor gene expression profiling improve outcomes in patients with breast cancer? Genet Med 2009, 11(1):66-73.
39. Kronenwett R, Bohmann K, Prinzler J, Sinn BV, Haufe F, Roth C, Averdick M, Ropers T, Windbergs C, Brase JC, Weber KE, Fisch K, Muller BM, Schmidt M, Filipits M, Dubsky P, Petry C, Dietel M, Denkert C: Decentral gene expression analysis: analytical validation of the Endopredict genomic multianalyte breast cancer prognosis test. BMC Cancer 2012, 12:456-2407. 12-456.

40. Elloumi F, Hu Z, Li Y, Parker JS, Gulley ML, Amos KD, Troester MA: Systematic bias in genomic classification due to contaminating nonneoplastic tissue in breast tumor samples. BMC Med Genomics 2011, 4(54):8794-4-54.

41. Mee BC, Carroll P, Donatello S, Connolly E, Griffin M, Dunne B, Burke L, Flavin R, Rizkalla H, Ryan C, Hayes B, D'Adhemar C, Banville N, Faheem N, Muldoon C, Gaffney EF: Maintaining Breast Cancer Specimen Integrity and Individual or Simultaneous Extraction of Quality DNA, RNA, and Proteins from Allprotect-Stabilized and Nonstabilized Tissue Samples. Biopreserv Biobank 2011, 9(4):389-398.

42. Graham K, Ge X, De Las MA, Tripathi A, Rosenberg CL: Gene expression profiles of estrogen receptor-positive and estrogen receptor-negative breast cancers are detectable in histologically normal breast epithelium. Clin Cancer Res 2011, 17(2):236-246.

43. Clare S, Pardo I, Mathieson T, Lillemoe H, Blosser R, Choi M, Sauder C, Doxey D, Badve S, Storniolo A, Atale R, Radovich M: "Normal" tissue adjacent to breast cancer is not normal [abstract]. Cancer Res 2012, 72(24 Suppl):P1-03-02.

doi:10.1186/1471-2407-14-177

Cite this article as: Nielsen et al:: Analytical validation of the PAM50based Prosigna Breast Cancer Prognostic Gene Signature Assay and nCounter Analysis System using formalin-fixed paraffin-embedded breast tumor specimens. BMC Cancer 2014 14:177.

\section{Submit your next manuscript to BioMed Central and take full advantage of:}

- Convenient online submission

- Thorough peer review

- No space constraints or color figure charges

- Immediate publication on acceptance

- Inclusion in PubMed, CAS, Scopus and Google Scholar

- Research which is freely available for redistribution

Submit your manuscript at www.biomedcentral.com/submit
C Biomed Central 